Article

\title{
Genotype X Environment Interaction Analysis of Faba Bean (Vicia faba L.) for Biomass and Seed Yield across Different Environments
}

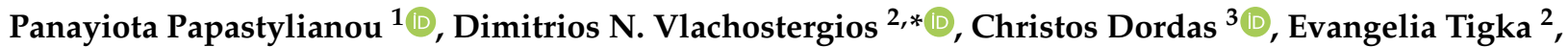 \\ Paschalis Papakaloudis ${ }^{3}$, Anastasia Kargiotidou ${ }^{2}$, Emmanouil Pratsinakis ${ }^{3}{ }^{(0}$, Avraam Koskosidis ${ }^{2}$,

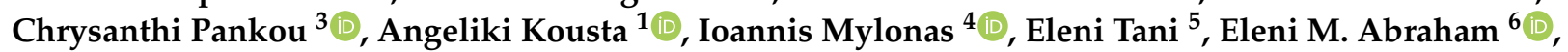 \\ Maria Karatassiou $^{6}$ and Stavroula Kostoula ${ }^{7}$
}

check for updates

Citation: Papastylianou, P.; Vlachostergios, D.N.; Dordas, C.; Tigka, E.; Papakaloudis, P.; Kargiotidou, A.; Pratsinakis, E.; Koskosidis, A.; Pankou, C.; Kousta, A.; et al. Genotype X Environment Interaction Analysis of Faba Bean (Vicia faba L.) for Biomass and Seed Yield across Different Environments. Sustainability 2021, 13, 2586. https:// doi.org/10.3390/su13052586

Academic Editor: António Dinis Ferreira

Received: 1 February 2021 Accepted: 24 February 2021 Published: 28 February 2021

Publisher's Note: MDPI stays neutral with regard to jurisdictional claims in published maps and institutional affiliations.

Copyright: (c) 2021 by the authors. Licensee MDPI, Basel, Switzerland. This article is an open access article distributed under the terms and conditions of the Creative Commons Attribution (CC BY) license (https:// creativecommons.org/licenses/by/ $4.0 /)$.
1 Laboratory of Agronomy, Department of Crop Science, Agricultural University of Athens, 11855 Athens, Greece; ppapastyl@aua.gr (P.P.); aggelikh.kousta@gmail.com (A.K.)

2 Institute of Industrial \& Forage Crops, Hellenic Agricultural Organization "Demeter", 41335 Larissa, Greece; evitiga@yahoo.gr (E.T.); nastia_kar@hotmail.com (A.K.); makisk47@gmail.com (A.K.)

3 Laboratory of Agronomy, School of Agriculture, Aristotle University of Thessaloniki, 54124 Thessaloniki, Greece; chdordas@agro.auth.gr (C.D.); pasxalis_pap@hotmail.com (P.P.); pratsina@agro.auth.gr (E.P.); cpankou@gmail.com (C.P.)

4 Institute of Plant Breeding \& Genetic Resources, HAO- "Demeter", 57101 Thessaloniki, Greece; ioanmylonas@yahoo.com

5 Laboratory of Plant Breeding \& Biometry, Department of Crop Science, Agricultural University of Athens, 11855 Athens, Greece; etani@aua.gr

6 Laboratory of Range Science, Department of Forestry \& Natural Environment, Aristotle University of Thessaloniki, 54124 Thessaloniki, Greece; eabraham@for.auth.gr (E.M.A.); karatass@for.auth.gr (M.K.)

7 Laboratory of Genetics \& Plant Breeding, Faculty of Agriculture, Aristotle University of Thessaloniki, 54124 Thessaloniki, Greece; staur_kostoula@yahoo.gr

* Correspondence: vlachostergios@gmail.com

\begin{abstract}
Development of high yielding and stable cultivars of various legume crops across different environments is very important for their adoption by farmers. In addition, climate change sets new challenges to major crop species and especially to grain legumes such as faba bean (Vicia faba L.) for adaptation to stressful environments. The present study focused on evaluating faba bean genotypes developed for yield and stability across different environments. The study was conducted in three areas of Greece (South, Central, and North) for two consecutive growing seasons (2018-2019 and 2019-2020). Biomass yield, seed yield, and yield components were studied together with plant height, earliness, and water use efficiency. Genotype, environment, and their interaction affected most of the studied characteristics. The environment was the major source of variation for most of the characteristics, as it explained $81-93 \%$ of total variation, and only in the thousand seed weight the variation was $49 \%$ for the environment and $40 \%$ for the genotype. Genotype had a much smaller effect on the remaining characteristics (1.2-3.9\%), and the interaction between environment $x$ genotype accounted for up to $0.5-17 \%$ of the variation. GGE-biplot analysis for high yield and stability across different environments revealed three genotypic types: genotypes well adapted either for biomass or seed yield and genotypes with high adaptation capacity for both traits under typical Mediterranean conditions. These results indicated that screening faba bean genotypes under different environmental field conditions is essential to identify adaptable cultivars to be cultivated for biomass and/or seed yield or to be used in breeding programs.
\end{abstract}

Keywords: evaluation; stability; seed yield; biomass yield; yield components; water use efficiency

\section{Introduction}

Agricultural productivity is highly affected by climatic change in terms of fluctuations in temperatures, precipitation, and extreme weather events, as well as variability in season- 
ality. At present, sustainable agriculture is threatened by climate change, as a reduction in crop production is expected in most regions [1]. Moreover, the changing conditions lead to resource problems, such as water shortage, pollution, soil deterioration, and ultimately food security issues in resource-poor regions [2].

The impact of climate change on agriculture can be reduced by modifying farming practices, and complementary to this, by using appropriate crops and varieties adapted to new climatic conditions. In this regard, modern breeding must fulfill several objectives: harmonize agricultural production and environment; ensure food and seed abundance, security and quality; and secure climate robustness [3]. Thus, breeding adaptive traits is required to increase the resilience to broad-spectrum stresses and maintain productivity, food security, and agricultural sustainability. At the same time, the demand for environmentally friendly crops and for food security has increased and has led to the establishment of cropping systems that include annual grain legumes [4]. Especially in the European Union, the policy is to greatly increase the domestic production of grain legumes $[5,6]$.

Although grain legumes are often characterized as climate-smart crops, they are mainly cultivated in marginal environments where the range and intensity of abiotic and biotic stresses are expected to increase [7]. Therefore, improving their resilience to climate change is of ultimate importance to provide food and nutritional security. Their narrow genetic diversity has always been a major drawback to their improvement for adaptability. To this end, plant breeders are required to intensify efforts to identify or develop diverse germplasm lines that can tolerate or even take advantage of climatic abnormalities [7].

Faba bean (Vicia faba L.) is one of the oldest crops grown by man, as it has been cultivated for c. 8000-10000 years and is native to the Near East and Mediterranean Basin area [8]. It is used as a human food because of its high protein, high starch content, and low lipid content; as feed for many animals; and for green manure [9]. It plays a vital role in farming systems as it provides ecological services for sustainable agriculture, such as soil enrichment with nitrogen and feeding habitat provision with nectar and pollen for pollinators [10-12]. It is the fourth most cultivated cool-season legume after pea (Pisum sativum L.), chickpea (Cicer arietinum L.), and lentil (Lens culinaris Medik.) worldwide [13]. However, faba bean acreage has declined from 4.8 million ha in 1970 to 2.4 in 2018 [14]. Moreover, dramatic decline was reported in Greece, where the acreage was reduced from 12,200 ha in 1970 to 968 ha in 2018 [14]. There are several reasons for this reduction, such as low and unstable yields and susceptibility to biotic and abiotic stresses [15-17]. Therefore, in order to increase the adoption of this crop it is important to adjust agricultural practices, to refine integrated pest management strategies, to develop genotypes resistant to major diseases and to abiotic stresses such as frost and water stress [18-20], and to improve the adaptation of genotypes to changing environment and nutritional quality by reducing the content of tannins and vicine-convicine in the seeds [9].

Faba bean is considered a crop species adapted to a wide range of climatic conditions and soil types [21]. However, its yield is unstable [5], as it is highly affected by environmental fluctuations [13]. Therefore, it is crucial to use stable genotypes well adapted to a wide range of environments. Together with good management practice, this will help increase production and acreage. This creates the need for the evaluation of genotype adaptability and stability to a wide range of environments [22], which requires multi-environment trials (METs). The study of cultivars and genotypes in METs allows breeders and agronomists to detect and understand genotype $x$ environment interaction (GEI) for the best-performing genotypes and genotype ranking in different environments $[23,24]$. In addition, climate change can affect the response of the genotypes in different environments [25]. Therefore, it is important to conduct experimentation in METs, which will help us understand and analyze GEI so that stable and widely adapted genotypes can be identified and recommended for production in the target environments.

Based on the above, it is evident that the yield stability of Vicia faba under different climatic and soil conditions is an important parameter for a sustainable farming system, especially nowadays with the large fluctuations of climatic factors from year to year. 
Therefore, the aim of the present study was to (i) evaluate Vicia faba genotypes (advanced lines and commercial cultivars) in three locations with clearly distinct environmental conditions for two consecutive years, (ii) to assess the genotype $\mathrm{x}$ environment interaction, (iii) to identify genotypes that have potential for specific and wide adaptation, and (iii) to identify environments that are more suitable for faba bean cultivation.

\section{Materials and Methods}

\subsection{Plant Material and Experimental Design}

Six faba bean genotypes, four advanced lines obtained by the company AGROLAND SA (namely G1: KK18; G2: KK101; G3: KK10; G4: KK14) and two commercial cultivars widely grown in Greece (namely G5: Polycarpe and G6: Tanagra) developed by the Institute of Industrial and Forage Crops (IIFC), were evaluated in a randomized complete blocks (RCB) design with four replications. Field experiments were conducted for two consecutive growing seasons: November-June 2018/2019 and November-June 2019/2020 at three locations: (1) the farm of the Agricultural University of Athens (AUA) (South Greece, Spata, latitude $37^{\circ} 58^{\prime} \mathrm{N}$, longitude $23^{\circ} 54^{\prime}$ E, elevation $123 \mathrm{~m}$ a.s.l.), (2) the central farm of IIFC (central Greece, Larissa, $39^{\circ} 30^{\prime} \mathrm{N}, 22^{\circ} 42^{\prime} \mathrm{E}$, elevation $77 \mathrm{~m}$ a.s.l.), and (3) the farm of the Aristotle University of Thessaloniki (AUTH) (North Greece, Thessaloniki, latitude $40^{\circ} 32^{\prime} \mathrm{N}$, longitude $22^{\circ} 59^{\prime} \mathrm{E}$, elevation $5 \mathrm{~m}$ a.s.l.). For each location, meteorological data and soil properties were recorded (Table 1). The plots consisted of three $3 \mathrm{~m}$-long rows with a distance of $0.25 \mathrm{~m}$ between rows. The seeding rate was $160 \mathrm{~kg} \mathrm{ha}^{-1}$. A balanced basal fertilization with $160 \mathrm{~kg} \mathrm{ha}^{-1}\left(0 \mathrm{~N}-46 \mathrm{P}_{2} \mathrm{O}_{5}-0 \mathrm{~K}_{2} \mathrm{O}\right)$ was pre-plant incorporated and appropriate cultural practices (weed removal by hand, disease and pest control) were followed. Plants were grown without supplemental irrigation in both growing seasons.

Table 1. Soil characteristics of the field trial during the cultivation period.

\begin{tabular}{cccccccc}
\hline Environment & Sand \% & $\begin{array}{c}\text { Clay } \\
\text { \% }\end{array}$ & $\begin{array}{c}\text { Loam } \\
\text { \% }\end{array}$ & pH & CaCO $_{3}(\%)$ & EC (mS/cm) & $\begin{array}{c}\text { Organic } \\
\text { Matter (\%) }\end{array}$ \\
\hline AUA, Southern Greece Env1 + Env2 & 50 & 26 & 24 & 7.9 & 11.6 & 3.0 & 1.43 \\
IIFC, Central Greece Env3 + Env4 & 20 & 57 & 23 & 8.0 & 1.5 & 4.9 & 1.30 \\
AUTH, Northern Greece Env5 + Env6 & 25 & 27 & 48 & 7.7 & 11.3 & 1.1 & 1.24 \\
\hline \multicolumn{7}{c}{ EC: electrical conductivity } \\
\hline
\end{tabular}

\subsection{Sampling and Measurement}

The following agronomical traits were recorded from the inner plant row in each plot as follows: seed yield, biomass yield, plant height, number of pods and seeds per plant, and 1000-seed weight. The extended BBCH scale [26] was used to describe the phenological development of the plants in each plot. Analytically, plant height, number of pods, and number of seeds per plant were determined as the average of 10 plants per plot. Plant height was monitored every 20 days throughout the growing periods, and the number of pods per plant and number of seeds per plant were determined at the physiological maturity stage (BBCH: 89). For the determination of biomass yield, $0.25 \mathrm{~m}^{2}$ were sampled in the middle row of each replicate plot to avoid any border effect, at the stage where over $50 \%$ of the plants were in full bloom and $20 \%$ of pods had reached their final length (BBCH: 72). All plant samples were cut to ground level with manual shears. The plant material was weighed fresh and was then oven-dried at $65{ }^{\circ} \mathrm{C}(3-4$ days) and weighed again to determine the respective dry weights. When each variety reached its physiological maturity stage (BBCH: 89), the experimental plots were hand-harvested and threshed using a laboratory thresher (Wintersteiger LD350) in order to assess seed yield. The harvested 
area was $0.50 \mathrm{~m}^{2}$ per plot, and seed yield was measured at $13 \%$ seed moisture content. Water use efficiency was calculated using the following Equation (1):

$$
W U E=\frac{\mathrm{Y}}{\mathrm{P}}
$$

where $\mathrm{Y}$ is the seed yield $\left(\mathrm{kg} \mathrm{ha}^{-1}\right)$ and $\mathrm{P}\left(\mathrm{m}^{3}\right)$ is the rainfall amount during the overall crop growth period.

\subsection{Statistical Analyses}

Combinations of location and growing season are referred to as Environments. Environment 1 (Env1) represents AUA 2018/2019, Environment 2 (Env2) represents AUA 2019/2020, Environment 3 (Env3) represents IIFC 2018/2019, Environment 4 (Env4) represents IIFC 2019/2020, Environment 5 (Env5) represents AUTH 2018/2019, and Environment 6 (Env6) represents AUTH 2019/2020. Data were subjected to over environment two-way analysis of variance (ANOVA), using the mixed model considering genotypes as fixed effect and environments as random effect [27]. The Tukey test at $a=0.05$ was used to compare means. Pearson correlation coefficients (r) were calculated to establish relationships between parameters. All the analyses were performed using the statistical SPSS18 software following the experimental design. In addition, a genotype and genotype $x$ environment (GGE) biplot analysis $[28,29]$ was conducted for the simultaneous determination of yield and stability across environments using GenStat software (13) [30].

\section{Results}

\subsection{Weather Conditions}

In general, the climate in Greece is Mediterranean, characterized as semi-arid with winter precipitation, cool winters, and hot summers. Weather data (rainfall, average, minimum and maximum air temperatures) were obtained from meteorological stations located within $1 \mathrm{~km}$ of the trial sites, recorded daily, and are reported as mean monthly data for the period in which the study was conducted (Figure 1, Tables 2 and 3). The testing environments differed substantially in terms of temperature and rainfall. Average air temperatures during the growing periods did not vary considerably from the longrun averages; however, from November 2019 to March 2020 (i.e., the second growing season), the average temperatures were higher than normal at all sites. The historical mean rainfall during the crop-growing season (November to June) is $346 \mathrm{~mm}, 310 \mathrm{~mm}$, and $318 \mathrm{~mm}$ at the Spata, Larissa, and Thessaloniki experimental locations, respectively, mainly concentrated between November and December. Rainfall at Larissa was higher than at the experimental station at Thessaloniki, whereas at both sites, the lowest values occurred in January and February, especially in the second growing season. Above-normal rainfall occurred in Spata, especially in winter and mid-spring $(436 \mathrm{~mm}$ in total, averaged across growing seasons) compared to the long-term average $(239 \mathrm{~mm})$. All crops received higher rainfall $(37 \%, 26 \%$, and $30 \%$ for Spata, Larissa, and Thessaloniki, respectively) during the second growing season than in the first. In addition, rainfall amounts and effective rainfall events $(>5 \mathrm{~mm})$ in Spata and Larissa were higher across late autumn and winter than in spring and early summer, whereas in Thessaloniki, the opposite occurred (Figure 1, Tables 2 and 3). Larissa and Thessaloniki were characterized by severe winter cold stress (absolute minimum temperatures were $-7.2^{\circ} \mathrm{C}$ and $-3.5^{\circ} \mathrm{C}$, respectively, in January) and more frost days in winter, especially in the first growing season (Table 2). Furthermore, in Spata and Larissa, higher absolute maximum temperatures and days with maximum temperature above $28{ }^{\circ} \mathrm{C}$ were recorded $\left(36.7^{\circ} \mathrm{C}\right.$ vs. $39.4^{\circ} \mathrm{C}$ and 11 vs. 17 , respectively) during May, especially in the second growing season (Table 3 ). 

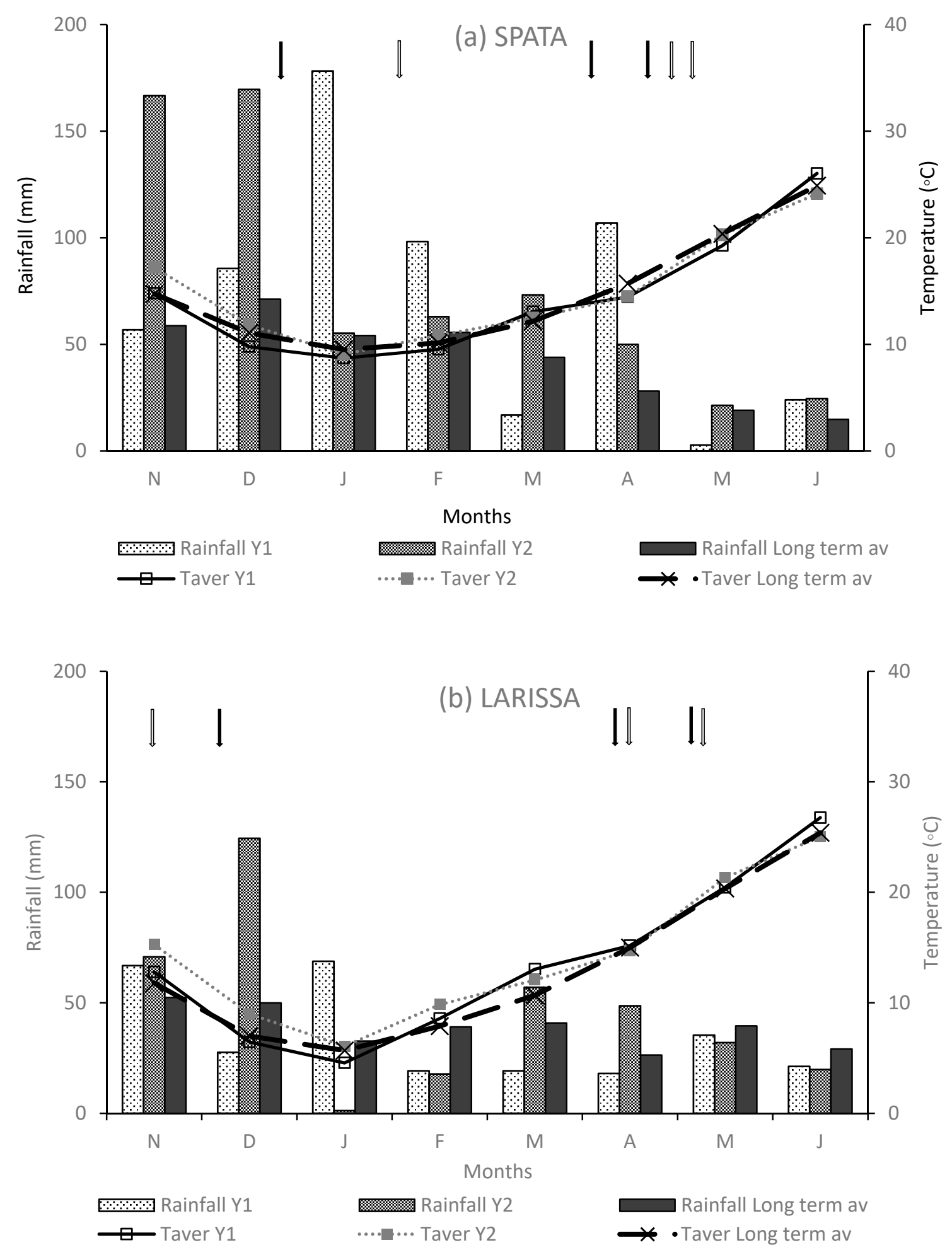

Figure 1. Cont. 


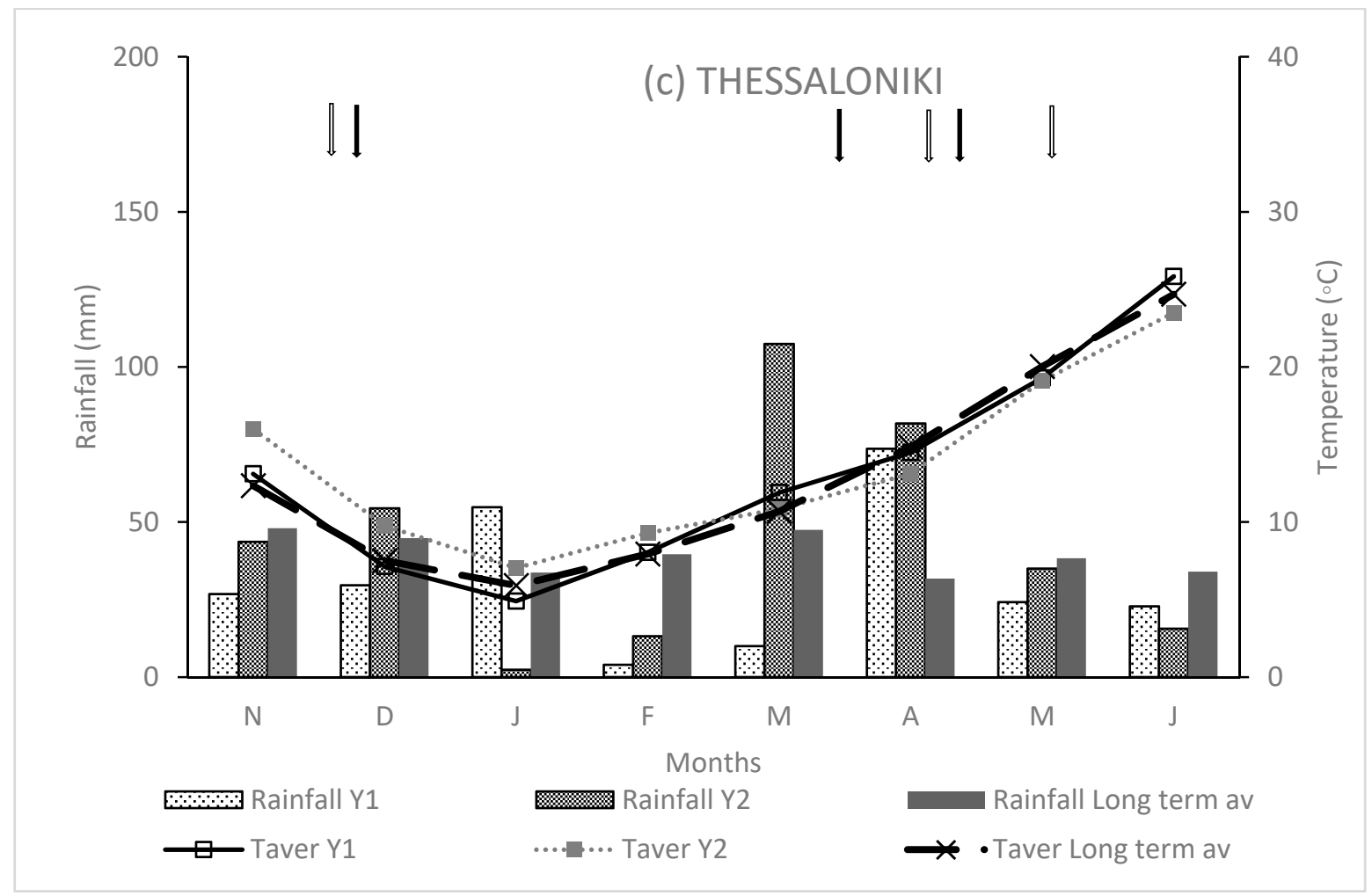

Figure 1. Monthly means of average ( $\mathrm{T}_{\text {aver }}$ ) air temperatures and rainfall for the 2018-2019 (Y1) and 2019-2020 (Y2) growing seasons and the 30-year average at the three locations (a) Spata, (b) Larissa, and (c) Thessaloniki, where the experiments were conducted. White and black arrows indicate sowing, flowering, and podding time for Y1 and Y2, respectively.

Table 2. Monthly means and 30-year averages for absolute (Abs Min T) and average (Av Min T) minimum temperatures $\left({ }^{\circ} \mathrm{C}\right)$, number of frost days (NFD) and number of days with effective rainfall ( $>5 \mathrm{~mm}$ ) (NDER) across late autumn and winter in the tested environments.

\begin{tabular}{|c|c|c|c|c|c|c|c|c|c|c|c|c|c|c|c|}
\hline & \multicolumn{5}{|c|}{ Env1 } & \multicolumn{5}{|c|}{ Env2 } & \multicolumn{5}{|c|}{ 30-Year Average Values } \\
\hline & Nov. & Dec. & Jan. & Feb. & N-F & Nov. & Dec. & Jan. & Feb. & $\mathrm{N}-\mathrm{F}$ & Nov. & Dec. & Jan. & Feb. & N-F \\
\hline Abs Min T & 7.0 & 3.0 & -1.0 & 2.6 & 2.9 & 11.5 & 3.4 & 2.4 & 1.3 & 4.7 & 4.8 & 0.8 & -0.3 & -0.1 & 1.3 \\
\hline Av Min T & 12.3 & 6.8 & 5.5 & 6.5 & 7.8 & 13.9 & 8.9 & 5.9 & 6.9 & 8.9 & 10.4 & 7.1 & 5.4 & 5.6 & 7.1 \\
\hline NFD & 0 & 0 & 3 & 0 & 3 & 0 & 0 & 0 & 0 & 0 & & & & & \\
\hline \multirow[t]{2}{*}{ NDER } & 4 & 5 & 9 & 7 & 25 & 7 & 7 & 3 & 3 & 20 & & & & & \\
\hline & \multicolumn{5}{|c|}{ Env3 } & \multicolumn{5}{|c|}{ Env4 } & \multicolumn{5}{|c|}{ 30-Year Average Values } \\
\hline Abs Min T & 6.2 & -1.8 & -7.2 & -0.9 & -0.9 & 7.5 & 0.8 & -3.6 & -1.2 & 0.9 & 0.7 & -3.4 & -5.6 & -2.7 & -2.8 \\
\hline Av Min T & 9.7 & 2.8 & 1.1 & 4.1 & 4.4 & 11.6 & 6.4 & 1.1 & 4.4 & 5.9 & 5.8 & 1.9 & 0.7 & 1.3 & 2.4 \\
\hline NFD & 0 & 4 & 12 & 2 & 18 & 0 & 0 & 14 & 3 & 17 & & & & & \\
\hline \multirow[t]{2}{*}{ NDER } & 4 & 2 & 5 & 1 & 12 & 6 & 4 & 0 & 2 & 12 & & & & & \\
\hline & \multicolumn{5}{|c|}{ Env5 } & \multicolumn{5}{|c|}{ Env6 } & \multicolumn{5}{|c|}{ 30-Year Average Values } \\
\hline Abs Min T & 4.1 & 1.3 & -3.5 & -0.3 & 0.4 & 10.2 & 2.4 & -0.1 & 1.5 & 3.5 & 1.7 & -1.8 & -4.4 & -1.9 & -1.6 \\
\hline Av Min T & 10.6 & 4.1 & 2.4 & 4.6 & 5.4 & 13.4 & 7.6 & 3.7 & 5.8 & 7.6 & 6.9 & 3 & 1.4 & 2.3 & 3.4 \\
\hline NFD & 0 & 0 & 7 & 1 & 8 & 0 & 0 & 1 & 0 & 1 & & & & & \\
\hline NDER & 3 & 2 & 3 & 0 & 8 & 2 & 4 & 0 & 1 & 7 & & & & & \\
\hline
\end{tabular}

Env1: Spata 2018/19; Env2: Spata 2019/20; Env3: Larissa 2018/19; Env4: Larissa 2019/20; Env5: Thessaloniki 2018/19; Env6: Thessaloniki 2019/20. 
Table 3. Monthly means and 30-year averages for absolute (Abs Max T) and average (Av Max T) maximum temperatures $\left({ }^{\circ} \mathrm{C}\right)$, number of days with absolute temperature up to $28{ }^{\circ} \mathrm{C}$ (NDMAX) and number of days with effective rainfall ( $\left.>5 \mathrm{~mm}\right)$ (NDER) across spring and early summer in the tested environments.

\begin{tabular}{|c|c|c|c|c|c|c|c|c|c|c|c|c|c|c|c|}
\hline & \multicolumn{5}{|c|}{ Env1 } & \multicolumn{5}{|c|}{ Env2 } & \multicolumn{5}{|c|}{ 30-Year Average Values } \\
\hline & Mar. & Apr. & May & Jun. & M-J & Mar. & Apr. & May & Jun. & M-J & Mar. & Apr. & May & Jun. & M-J \\
\hline Abs Max T & 23.3 & 26.3 & 31.7 & 35.6 & 29.2 & 22.4 & 25.6 & 36.7 & 33.8 & 29.6 & 21.9 & 25.7 & 31.5 & 36.8 & 29 \\
\hline Av Max T & 17.6 & 19.1 & 25.2 & 30.6 & 23.1 & 16.8 & 19.2 & 26.7 & 29.2 & 23.0 & 15.6 & 19.6 & 24.8 & 29.7 & 22.4 \\
\hline NDMAX & 0 & 0 & 6 & 11 & 17 & 0 & 0 & 11 & 10 & 21 & & & & & \\
\hline \multirow[t]{2}{*}{ NDER } & 2 & 5 & 0 & 0 & 7 & 4 & 3 & 2 & 0 & 9 & & & & & \\
\hline & \multicolumn{5}{|c|}{ Env3 } & \multicolumn{5}{|c|}{ Env4 } & \multicolumn{5}{|c|}{ 30-Year Average Values } \\
\hline Abs Max T & 25.9 & 30.8 & 33.1 & 38.7 & 32.1 & 25.7 & 30.6 & 39.4 & 37.3 & 33.3 & 24.1 & 28.0 & 33.5 & 38.8 & 31.1 \\
\hline Av Max T & 19.9 & 21.4 & 27.5 & 33.2 & 25.5 & 18.8 & 21.4 & 29.1 & 31.1 & 25.1 & 14.9 & 19.8 & 25.8 & 31.1 & 22.9 \\
\hline NDMAX & 0 & 4 & 14 & 14 & 32 & 0 & 5 & 17 & 11 & 33 & & & & & \\
\hline \multirow[t]{2}{*}{ NDER } & 1 & 1 & 3 & 0 & 5 & 5 & 3 & 1 & 1 & 10 & & & & & \\
\hline & \multicolumn{5}{|c|}{ Env5 } & \multicolumn{5}{|c|}{ Env6 } & \multicolumn{5}{|c|}{ 30-Year Average Values } \\
\hline Abs Max T & 22.8 & 24.8 & 29.0 & 35.2 & 28.0 & 23.2 & 24.7 & 31.9 & 35.3 & 28.8 & 21.5 & 26.1 & 30.4 & 35.5 & 28.4 \\
\hline Av Max T & 17.1 & 18.9 & 24.6 & 30.4 & 22.8 & 15.3 & 18.0 & 24.3 & 27.1 & 21.2 & 14.3 & 19.2 & 24.5 & 29.3 & 21.8 \\
\hline NDMAX & 0 & 0 & 4 & 11 & 15 & 0 & 0 & 3 & 4 & 7 & & & & & \\
\hline NDER & 1 & 4 & 2 & 1 & 8 & 8 & 5 & 1 & 1 & 15 & & & & & \\
\hline
\end{tabular}

Env1: Spata 2018/19; Env2: Spata 2019/20; Env3: Larissa 2018/19; Env4: Larissa 2019/20; Env5: Thessaloniki 2018/19; Env6: Thessaloniki 2019/20.

\subsection{Agronomic Traits}

Based on the combined analysis of variance, a significant effect of environment $(\mathrm{E})$ was observed on biomass yield, seed yield, yield components, plant height, earliness, and water use efficiency for biomass and seed yield $(p<0.001)$, reflecting the variation of soil-climatic conditions in each location and growing season. Genotype demonstrated significant effect on biomass yield, thousand seed weight and earliness $(p<0.001)$, pods and seeds per plant $(p$ $<0.01$ ), seed yield ( $p<0.05)$, and WUE for biomass and seed yield, whereas the same effect was insignificant on plant height. All yield determinants, earliness, and WUE for seed yield also showed a large genotype $x$ environment interaction $(p<0.001)$. Environment significantly explained up to $80 \%$ of the total sum of squares in all traits except thousand seed weight, where genotype and environment components were of similar magnitude (Table 4).

Table 4. Combined analysis of variance of six faba bean genotypes across six environments for various characteristics at harvest. Plant height (PH), number of pods per plant (PP), number of seeds per plant (SP), 1000-seed weight (TSW), seed yield (SY), earliness, biomass yield (BY), water use efficiency for biomass yield (WUE $\mathrm{BY}$ ), and water use efficiency for seed yield (WUESY).

\begin{tabular}{|c|c|c|c|c|c|c|c|c|c|c|c|}
\hline & \multicolumn{3}{|c|}{ BY $\left(t a^{-1}\right)$} & \multicolumn{2}{|c|}{ SY (t ha-1) } & \multicolumn{2}{|c|}{ PP } & \multicolumn{2}{|c|}{ SP } & \multicolumn{2}{|c|}{ TSW (g) } \\
\hline & df & MS & EV\% & MS & EV\% & MS & EV\% & MS & EV\% & MS & EV\% \\
\hline E & 5 & $186^{* * *}$ & 88.4 & $31.7^{* * *}$ & 81 & $1803^{* * *}$ & 88.3 & $21,217^{* * *}$ & 88 & $121,632 * * *$ & 49.4 \\
\hline G & 5 & $8.28^{* * *}$ & 3.9 & 0.96 * & 2.4 & $48.5^{* *}$ & 2.4 & $647^{* *}$ & 2.7 & $99,365^{* * *}$ & 40.4 \\
\hline \multirow[t]{2}{*}{ GxE } & 25 & $3.25 *$ & 7.7 & $1.31^{* * *}$ & 16.6 & $37.9^{* * *}$ & 9.3 & $448^{* *}$ & 9.3 & $5037^{* * *}$ & 10.2 \\
\hline & & \multicolumn{2}{|c|}{$\mathrm{PH}(\mathrm{cm})$} & \multicolumn{2}{|c|}{ Earliness (DAS) } & \multicolumn{2}{|c|}{ WUE $_{\mathrm{BY}}\left(\mathrm{kg} \mathrm{ha}^{-1} \mathrm{~m}^{-3}\right)$} & \multicolumn{2}{|c|}{ WUE $_{S Y}\left(\mathrm{~kg} \mathrm{ha}^{-1} \mathrm{~m}^{-3}\right)$} & & \\
\hline $\mathrm{E}$ & 5 & $11,520 * * *$ & 93 & $14,157^{* * *}$ & 98.2 & $28.2 * * *$ & 88.7 & $4.05^{* * *}$ & 80.7 & & \\
\hline G & 5 & $152.4^{\mathrm{ns}}$ & 1.2 & $188^{* * *}$ & 1.3 & $1.13^{* *}$ & 3.6 & $0.12 *$ & 2.4 & & \\
\hline GxE & 25 & $142.4^{*}$ & 5.8 & $13.0^{* * *}$ & 0.5 & $0.49 *$ & 7.7 & $0.17^{* * *}$ & 16.9 & & \\
\hline
\end{tabular}

df: degrees of freedom; MS: mean squares; EV: \% variation respect (E + G + GxE) sum of squares; DAS: days after sowing; ns: non-significant $(p>0.05) ;{ }^{*}, * * * * *$ significant at $p<0.05, p<0.01$, and $p<0.001$ levels of probability, respectively.

The genotypes showed a different response for plant height across the tested environments. The tallest plant height was recorded at Env4 $(129.6 \mathrm{~cm})$ with insignificant height differences between the cultivars across environments, whereas the shortest plant height was recorded at 
Env1 and Env5 in the first growing season (Tables 5 and 6). Regarding seed yield, G1 and G6 out-yielded other genotypes (3.01 and $3.07 \mathrm{t} \mathrm{ha}^{-1}$, respectively), whereas G5 performed poorly $\left(2.5 \mathrm{tha}^{-1}\right)$. Average seed yield over genotypes was highest at Env6 $\left(4.12 \mathrm{tha}^{-1}\right)$ followed by both growing seasons at Larissa (Env3 and Env4). The lowest value was recorded at Env5 (0.74 $\mathrm{t} \mathrm{ha}^{-1}$ ). In the case of biomass yield, genotypes G3, G4, G2, and G6 showed above-average values $\left(8.86 \mathrm{t} \mathrm{ha}^{-1}\right)$, whereas the lowest values were recorded for G1 and G5. Among the tested environments, the highest biomass production was observed in both growing seasons at Larissa and at Thessaloniki 2019/2020 (Env4 and Env6). The lowest biomass yield was produced at Env1 $\left(4.7 \mathrm{tha}^{-1}\right)$. The number of pods and seeds per plant ranged between 15.5 (G1) and 18.1 (G5) and between 48.8 (G1) and 57.6 (G5), respectively, showing no significant differences among the genotypes except for G4, which exhibited the lowest values (14.4 and 43.6, respectively). The highest number of pods and seeds was recorded at Env2 (28.9 and 97.6, respectively) and the lowest at Env5 (4.17 and 13.4, respectively). Intermediate values were recorded at Larissa without differences between the two growing seasons. The second experimental season showed taller plants, higher biomass production, and a bigger number of pods and seeds per plant than the first in all experimental locations (Table 6). The average thousand-seed weight of cultivars across environments was $484 \mathrm{~g}$. Genotypes G1 and G2 produced the highest thousand-seed weight, whereas G5 resulted in the lowest value ( $371 \mathrm{~g}$ ). In the tested environments the highest $(585 \mathrm{~g})$ and lowest $(396 \mathrm{~g})$ thousand-seed weights were recorded at Env6 and Env1, respectively (Tables 5 and 6). Among genotypes, time to flowering fluctuated between 117 to 125 days from sowing. Genotypes 1 and 6 presented the earliest initiation of flowering, whereas G5 was the latest. Genotypes showed early flowering at Env1 but flowering late at Larissa and Thessaloniki in the first growing season (153 and 135 days from sowing, respectively). WUE efficiency for biomass and seed yield was lowest for the G5 genotype, whereas G3 and G4 ranked in the top for WUE $E_{B Y}$ and $G 6$ for WUE $E_{S Y}$.

Table 5. Average values across environments of faba bean genotypes for various characteristics at harvest. Plant height (PH), number of pods per plant (PP), number of seeds per plant (SP), 1000-seed weight (TSW), seed yield (SY), earliness in days after sowing (DAS), biomass yield (BY), water use efficiency for biomass yield (WUE $\mathrm{BY}_{\mathrm{BY}}$ ), and water use efficiency for seed yield (WUESY).

\begin{tabular}{|c|c|c|c|c|c|c|c|c|c|}
\hline Genotype & $\begin{array}{c}\text { BY } \\
\left(\mathrm{t} \mathrm{ha}^{-1}\right)\end{array}$ & $\begin{array}{c}S Y \\
\left(t \mathrm{ha}^{-1}\right)\end{array}$ & $\begin{array}{c}\mathrm{PH} \\
(\mathrm{cm})\end{array}$ & PP & SP & $\underset{\text { (g) }}{\text { TSW }}$ & $\begin{array}{l}\text { Earliness } \\
\text { (DAS) }\end{array}$ & $\begin{array}{c}\text { WUE }_{B Y} \\
\left(\mathrm{~kg} \mathrm{ha}^{-1} \mathrm{~m}^{-3}\right)\end{array}$ & $\begin{array}{c}\text { WUE }_{S Y} \\
\left(\mathrm{~kg} \mathrm{ha}^{-1} \mathrm{~m}^{-3}\right)\end{array}$ \\
\hline G1 & 8.44 bc & $3.01 \mathrm{a}$ & $89.2 \mathrm{a}$ & $15.5 \mathrm{ab}$ & $48.8 \mathrm{ab}$ & $542.6 \mathrm{a}$ & $116.6 \mathrm{e}$ & $3.49 \mathrm{ab}$ & $1.08 \mathrm{ab}$ \\
\hline G2 & $8.85 \mathrm{abc}$ & $2.85 \mathrm{ab}$ & $88.2 \mathrm{a}$ & $16.5 \mathrm{ab}$ & $50.2 \mathrm{ab}$ & $534.2 \mathrm{ab}$ & $121.3 \mathrm{~b}$ & $3.66 \mathrm{ab}$ & $1.06 \mathrm{ab}$ \\
\hline G3 & $9.46 \mathrm{ab}$ & $2.90 \mathrm{ab}$ & $94.0 \mathrm{a}$ & $17.9 \mathrm{a}$ & $56.6 \mathrm{a}$ & $497.2 \mathrm{c}$ & $121.5 \mathrm{~b}$ & $3.87 \mathrm{a}$ & $1.06 \mathrm{ab}$ \\
\hline G4 & $9.53 \mathrm{a}$ & $2.83 \mathrm{ab}$ & $91.3 \mathrm{a}$ & $14.4 \mathrm{~b}$ & $43.6 \mathrm{~b}$ & $448.8 \mathrm{~d}$ & $120.7 \mathrm{C}$ & $3.93 \mathrm{a}$ & $1.05 \mathrm{ab}$ \\
\hline G5 & $8.00 \mathrm{c}$ & $2.50 \mathrm{~b}$ & $88.8 \mathrm{a}$ & $18.1 \mathrm{a}$ & $57.6 \mathrm{a}$ & $371.0 \mathrm{e}$ & $124.6 \mathrm{a}$ & $3.36 \mathrm{~b}$ & $0.92 \mathrm{~b}$ \\
\hline G6 & $8.86 \mathrm{abc}$ & $3.07 \mathrm{a}$ & $87.0 \mathrm{a}$ & $16.1 \mathrm{ab}$ & $52.2 \mathrm{ab}$ & 507.9 bc & $118.1 \mathrm{~d}$ & $3.68 \mathrm{ab}$ & $1.13 \mathrm{a}$ \\
\hline Tukey (0.05) & 1.08 & 0.475 & 7.35 & 3.08 & 11.4 & 27.3 & 0.505 & 0.172 & 0.454 \\
\hline
\end{tabular}

G1: KK18; G2: KK101; G3: KK10; G4: KK14; G5: Polycarpe; G6: Tanagra. DAS: days after sowing; Different letters within a column indicate significant differences according to the Tukey test $(p<0.05)$.

Table 6. Values in each testing environment averaged across faba bean genotypes for various characteristics at harvest. Plant height (PH), number of pods per plant (PP), number of seeds per plant (SP), 1000-seed weight (TSW), seed yield $(\mathrm{SY})$ ), earliness, biomass yield (BY), water use efficiency for biomass yield (WUEBY), and water use efficiency for seed yield (WUESY).

\begin{tabular}{|c|c|c|c|c|c|c|c|c|c|}
\hline Environment & $\begin{array}{c}\text { BY } \\
\left(\mathrm{t} \mathrm{ha}^{-1}\right)\end{array}$ & $\begin{array}{c}S Y \\
\left(t \mathrm{ha}^{-1}\right)\end{array}$ & $\begin{array}{c}\mathrm{PH} \\
(\mathrm{cm})\end{array}$ & PP & SP & $\begin{array}{c}\text { TSW } \\
\text { (g) }\end{array}$ & $\begin{array}{l}\text { Earliness } \\
\text { (DAS) }\end{array}$ & $\begin{array}{c}\text { WUE }_{B Y} \\
\left(\mathrm{~kg} \mathrm{ha}^{-1} \mathrm{~m}^{-3}\right)\end{array}$ & $\begin{array}{c}\text { WUE }_{S Y} \\
\left(\mathrm{~kg} \mathrm{ha}^{-1} \mathrm{~m}^{-3}\right)\end{array}$ \\
\hline Env1 & $4.70 \mathrm{~d}$ & $2.99 \mathrm{bc}$ & $71.2 \mathrm{~d}$ & $16.6 \mathrm{c}$ & $48.8 \mathrm{c}$ & $395.7 \mathrm{~d}$ & $81.9 \mathrm{f}$ & $2.09 \mathrm{e}$ & $1.32 \mathrm{ab}$ \\
\hline Env2 & $9.45 \mathrm{~b}$ & $2.64 \mathrm{c}$ & $90.8 \mathrm{bc}$ & $28.9 \mathrm{a}$ & $97.6 \mathrm{a}$ & $516.1 \mathrm{~b}$ & $113.1 \mathrm{~d}$ & $2.83 \mathrm{~d}$ & $0.74 \mathrm{c}$ \\
\hline Env3 & $10.5 \mathrm{a}$ & $3.35 \mathrm{~b}$ & $93.7 \mathrm{~b}$ & $12.5 \mathrm{~d}$ & $36.7 \mathrm{~d}$ & $463.7 \mathrm{c}$ & $152.5 \mathrm{a}$ & $4.25 \mathrm{~b}$ & $1.23 \mathrm{~b}$ \\
\hline Env4 & $11.4 \mathrm{a}$ & $3.31 \mathrm{~b}$ & $129.6 \mathrm{a}$ & $13.2 \mathrm{~d}$ & $39.4 \mathrm{~cd}$ & $418.0 \mathrm{~d}$ & $129.3 \mathrm{c}$ & $4.95 \mathrm{a}$ & $1.21 \mathrm{~b}$ \\
\hline Env5 & $6.13 c$ & $0.74 \mathrm{~d}$ & $69.4 \mathrm{~d}$ & $4.17 \mathrm{e}$ & $13.4 \mathrm{e}$ & $523.3 \mathrm{~b}$ & $135.0 \mathrm{~b}$ & $3.41 \mathrm{c}$ & $0.37 \mathrm{~d}$ \\
\hline Env6 & $10.9 \mathrm{a}$ & $4.12 \mathrm{a}$ & $83.9 c$ & $23.0 \mathrm{~b}$ & $73.2 \mathrm{~b}$ & $584.9 \mathrm{a}$ & $111.0 \mathrm{e}$ & $4.47 \mathrm{~b}$ & $1.43 \mathrm{a}$ \\
\hline Tukey (0.05) & 1.08 & 0.475 & 7.35 & 3.08 & 11.4 & 27.3 & 0.505 & 0.172 & 0.454 \\
\hline
\end{tabular}

Env1: Spata 2018/19; Env2: Spata 2019/20; Env3: Larissa 2018/19; Env4: Larissa 2019/20; Env5: Thessaloniki 2018/19; Env6: Thessaloniki 2019/20. DAS: days after sowing; Different letters within a column indicate significant differences according to the Tukey test $(p<0.05)$. 


\subsection{Correlation between Traits}

The Pearson correlation coefficients of agronomic traits of faba bean genotypes for all environments are presented in Table 7. Biomass yield was significantly and positively correlated to all traits. The strongest correlation was found between biomass yield and plant height $(r=0.674, p<0.01)$. Seed yield was significantly and positively correlated to plant height and pods and seeds per plant and negatively correlated to earliness. No significant correlations were observed between plant height, pods and seeds per plant, or thousand-seed weight. Number of seeds per plant was closely associated with number of pods and thousand-seed weight. Earliness was negatively correlated to pods and seeds per plant and positively to plant height.

Table 7. Pearson correlation coefficients and levels of significance between agronomic traits. Plant height (PH), number of pods per plant (PP), number of seeds per plant (SP), 1000-seed weight (TSW), seed yield (SY), earliness (EAR), and biomass yield (BY). Data were combined over genotypes, environments, and replications $(n=144)$.

\begin{tabular}{|c|c|c|c|c|c|c|}
\hline & BY & SY & PH & PP & SP & TSW \\
\hline SY & $0.455^{* *}$ & & & & & \\
\hline PH & $0.674^{* *}$ & $0.380 * *$ & & & & \\
\hline PP & $0.263^{* *}$ & $0.491^{* *}$ & $0.068^{\mathrm{ns}}$ & & & \\
\hline SP & $0.237^{* *}$ & $0.439 * *$ & $0.050^{\mathrm{ns}}$ & $0.977^{* *}$ & & \\
\hline TSW & $0.202 *$ & $0.126^{\mathrm{ns}}$ & $-0.158^{\mathrm{ns}}$ & $0.141^{\mathrm{ns}}$ & 0.176 * & \\
\hline EAR & $0.440^{* *}$ & -0.173 * & $0.320^{* *}$ & $-0.404^{* *}$ & $-0.374^{* *}$ & $0.071^{\mathrm{ns}}$ \\
\hline
\end{tabular}

\subsection{Adaptability and Stability Analysis (GGE Biplot AMMI) for Biomass and Seed Yield}

The GGE biplot analysis explained $89.25 \%$ of total variability, and revealed that the highest biomass production genotype G4 (noted as $\times 4$ ) was positioned closest to the point of the "ideal genotype" in terms of performance and stability across environments. Second in the ranking was genotype G3 (noted as x3) (Figure 2). The angle between environmental vectors provides information about the correlation between environments (Figure 3). A high positive correlation was found between the lowest biomass production environment Env1 and between high biomass production environments Env3 and Env4. In addition, a positive correlation was found between environments Env1, Env2, Env3, and Env4. A high negative correlation was found between low biomass production environment Env5 and high biomass production environment Env6. High biomass production environment Env6 showed no correlation with high biomass production environments Env3 and Env4 or with environments Env1 and Env2. Respectively, low biomass production environment Env5 showed no correlation with the lowest biomass production environment Env1 and environments Env2, Env3, or Env4. The "which-won-where" view of the GGE biplot (Figure 4) indicated three mega-environments, e.g., environments Env2, Env3, and Env1 formed the first mega-environment with G3 as the winning genotype; high biomass production environments Env6 and Env4 formed the second mega-environment with G4 as the winning genotype; and the third mega-environment consisted of low biomass production environment Env5 with G5 as the winning genotype. 


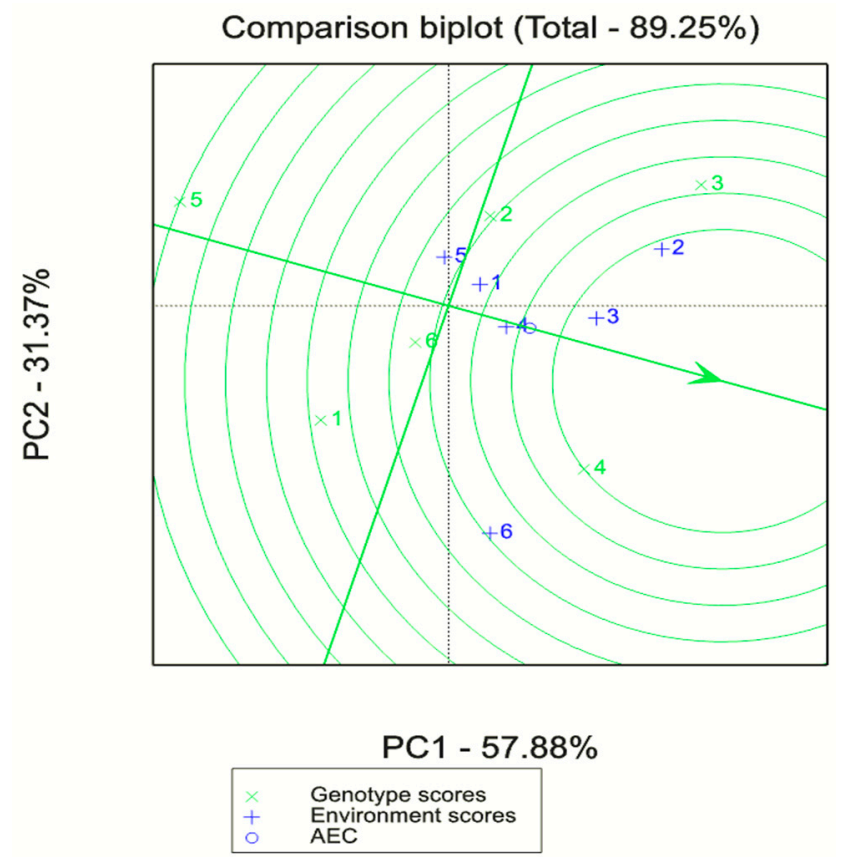

Figure 2. Genotype and genotype by environment (GGE) biplot for biomass production of the 6 genotypes evaluated in 6 environments (" $x$ " code corresponds to genotypes and " + " code to environments).

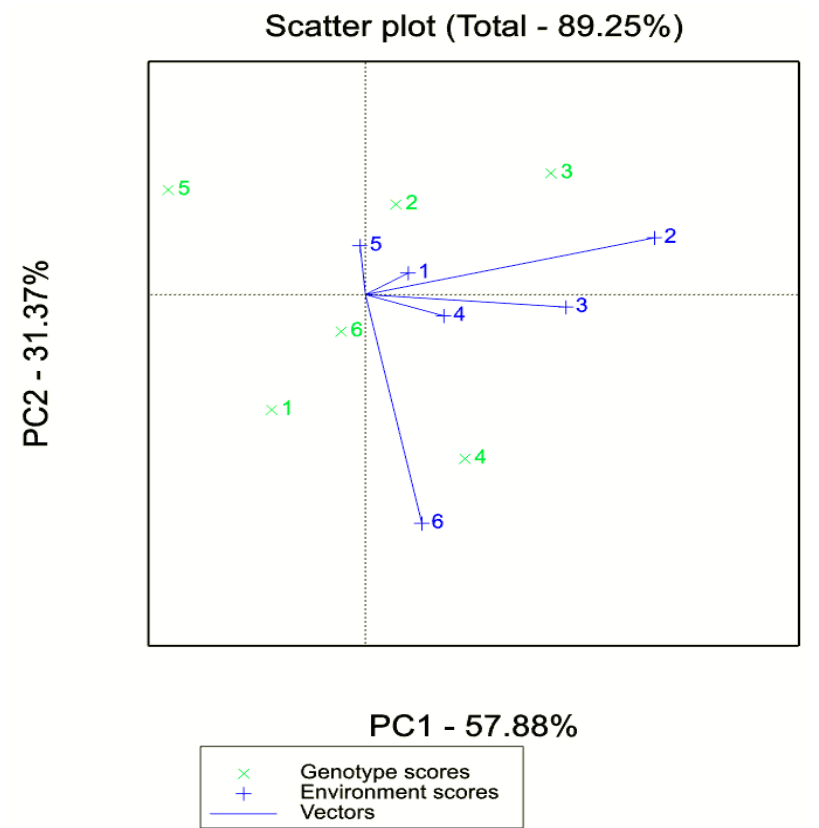

Figure 3. Genotype and genotype by environment (GGE) scatter plot for biomass production of the 6 genotypes evaluated in 6 environments (" $x$ " code corresponds to genotypes, " + " code to environments, blue line vectors connect the environments with the origin).

The GGE biplot analysis explained $77.46 \%$ of total variability, and revealed that the highest seed production genotype G6 (noted as x6) was positioned closest to the point of the "ideal genotype" in terms of performance and stability across environments. Second in the ranking was genotype G3 (noted as x3) (Figure 5). The angle between environmental vectors provides information about the correlation between environments (Figure 6). A high positive correlation was found between environment Env1 (noted as +1 ) and Env3 (noted as +3 ). A high negative correlation was found between environments Env3 (noted as +3 ) and Env4 (noted as +4) with environment Env1 (noted as +1). The "which-won-where" 
view of the GGE biplot (Figure 7) indicated three mega-environments, e.g., environments Env3, Env1, and Env5 formed the first mega-environment with G3 as the winning genotype; environments Env6 and Env2 formed the second mega-environment with G1 as the winning genotype; and the third mega-environment consisted of environment Env4 with G5 as the winning genotype.
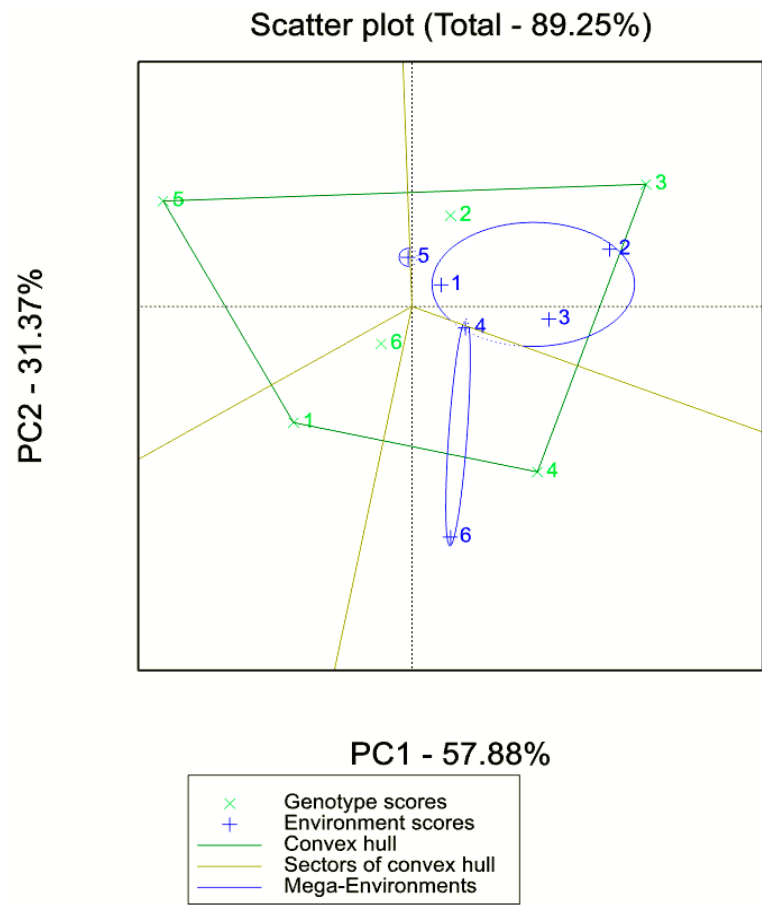

Figure 4. The GGE biplot analysis of biomass production for the "which-won-where" pattern across environments (Figure 3) (" $x$ " code corresponds to genotypes, "+" code to environments, furthest genotypes are connected to form a polygon, elliptical and oval shape represent mega-environments).

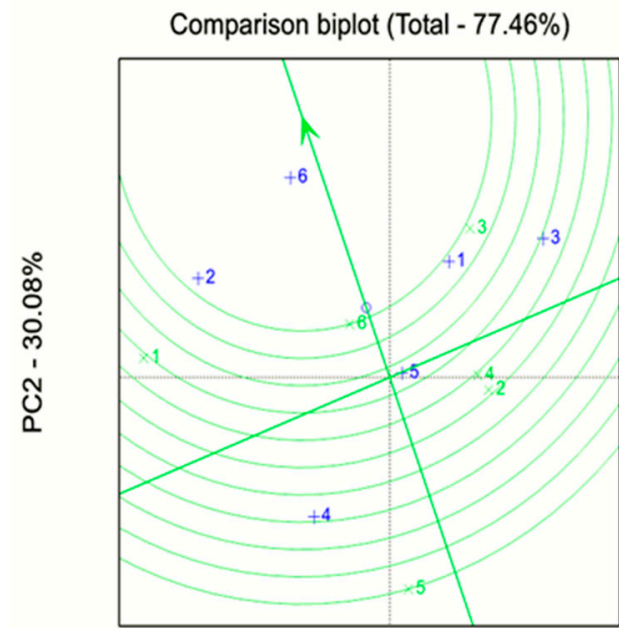

PC1 $-47.38 \%$

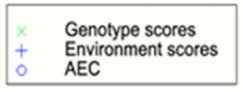

Figure 5. Genotype and genotype by environment (GGE) biplot for seed yield of the 6 genotypes evaluated in 6 environments (" $x$ " code corresponds to genotypes and " + " code to environments). 


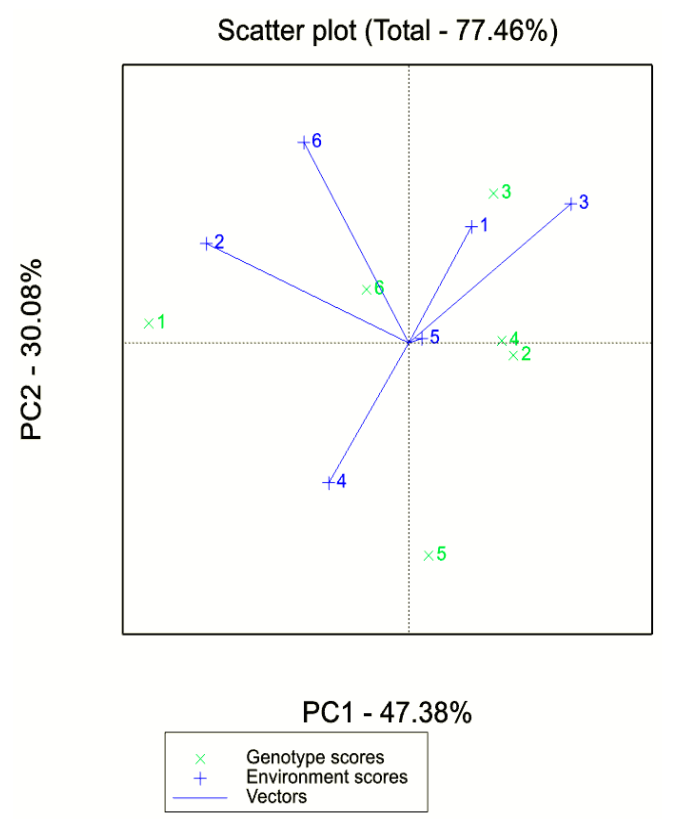

Figure 6. Genotype and genotype by environment (GGE) scatter plot for seed yield of the 6 genotypes evaluated in 6 environments: (" $x$ " code corresponds to genotypes, "+" code to environments, blue line vectors connect the environments with the origin).

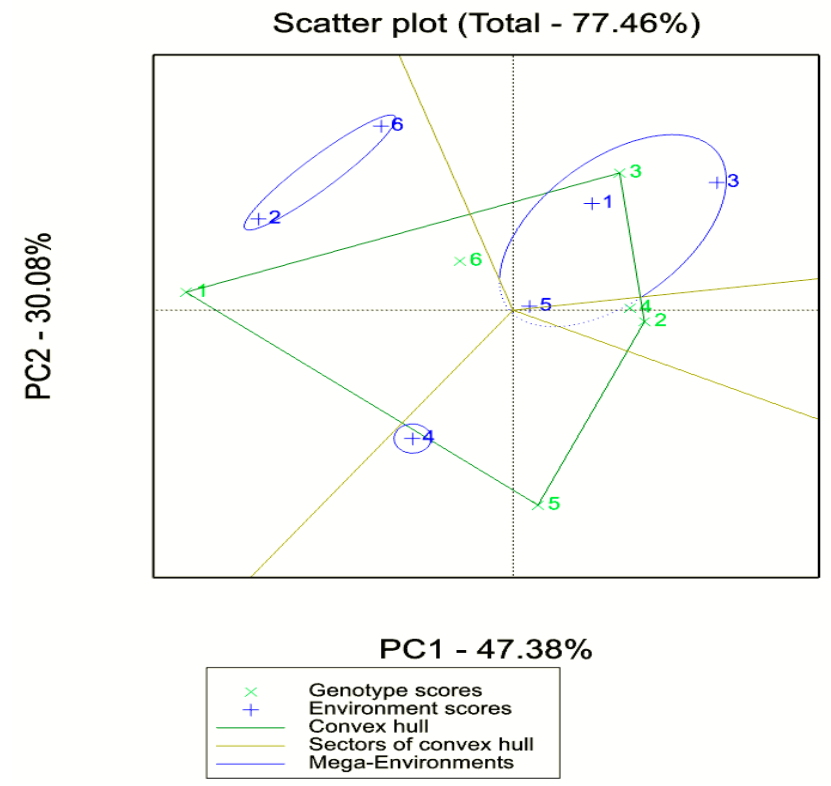

Figure 7. The GGE biplot analysis of seed yield for the "which-won-where" pattern across environments (Figure 5) (" $x$ " code corresponds to genotypes, " + " code to environments, furthest genotypes are connected to form a polygon, elliptical and oval shapes represent mega-environments).

\section{Discussion}

Faba bean is a grain legume grown worldwide as a protein source for food and feed. In addition, faba bean offers essential ecosystem services such as renewable inputs of nitrogen $(\mathrm{N})$ in the cropping system through biological $\mathrm{N}_{2}$ fixation and diversification of cropping systems, improving cropping systems' sustainability. Even though the average seed yield has almost doubled during the last 50 years, the total area grown with faba beans has declined by $56 \%$ over the same period [14]. The reasons behind this decline are the variability in grain yield across seasons, the limited adaptability of the genotypes to 
the changing environment, the extensive use of cereal monoculture across many countries, and the use of chemical fertilizers [18].

\subsection{Weather Conditions}

In the present study, six genotypes of faba bean were studied across six different environments. A significant effect was found across the different environments and among the different genotypes. The three areas selected for the experiments were located in south, central, and northern Greece and showed significant differences in the main pedoclimatic parameters such as air temperature, rainfall, and soil conditions, which resulted in six different environments typical of the Mediterranean area. Moreover, during the second year the air temperature was higher in all areas and this variation was crucial for studying the genotype $\mathrm{x}$ environment interaction [25,31]. Differences between environments are important for studies in grain legumes such as faba bean, as they determine the adaptability of genotypes across environments and dissect the GxE interaction [23,32].

Grain legume instability has increased over the last 60 years [33] due to ongoing climate change as crop plants are exposed to above-normal optimal temperatures and/or water deficits [34]. Similarly, in our study, it was observed that in some environments the temperature was quite high $\left(36.7^{\circ} \mathrm{C}\right.$ and $39.4{ }^{\circ} \mathrm{C}$ in Env2 and Env4, respectively) at the critical stage of the grain-filling period [35]. In addition, lower than normal rainfall occurred in Env5 (196 mm). As a consequence, the abovementioned climatic conditions significantly reduced the seed yield and yield components [36,37]. Legume crops in many areas and especially in Mediterranean conditions suffer from heat and water stress and other environmental factors that significantly reduce yield performance [38,39].

\subsection{Agronomic Traits}

Environment and genotype $x$ environment interaction (GEI) affected all of the agronomic traits studied, i.e., biomass yield, seed yield, yield components, thousand-seed weight, plant height, and earliness, whereas genotypes affected all the above traits except for plant height. The environment was the major source of variation, as it explained more than $80 \%$ of the total variation in all traits except for the thousand-seed weight, where the variation was $49 \%$ for the environment and $40 \%$ for the genotype. In addition, the relatively large magnitude of the $G \times E$ interaction sum of squares observed in all traits except thousand-seed weight and earliness was from two to six times larger than that for genotype. This indicated that there were sizable differences in responses according to genotype across environments [40].

Biomass yield ranged from 8.00 to $9.53 \mathrm{t} \mathrm{ha}^{-1}$, which is in agreement with similar studies in the same area [41]. The highest biomass yield was recorded at G4 and the lowest at G5. The most productive environments were Env3 $\left(10.5 \mathrm{t} \mathrm{ha}^{-1}\right)$ and Env4 $\left(11.4 \mathrm{t} \mathrm{ha}^{-1}\right)$, which corresponded to the same location (Larissa), and the lowest was Env1 $\left(4.7 \mathrm{tha}^{-1}\right)$. The accumulation of biomass is an important characteristic as it relates positively to the final seed yield [36,42], something that was moderately observed in the present study, as the correlation coefficient for the two traits was 0.455 .

Seed yield was affected by the different genotypes, and the highest was at G1 and G6, with 3.01 and $3.07 \mathrm{tha}^{-1}$, respectively, whereas the G5 genotype had the lowest seed yield with $2.5 \mathrm{t} \mathrm{ha}^{-1}$. Similar seed yields were found in other studies in the Mediterranean area $[43,44]$, indicating that these genotypes can be cultivated in this area. In addition, an interesting differentiation was found between the environments. Env6 was the most productive $\left(4.12 \mathrm{t} \mathrm{ha}^{-1}\right)$, followed by Env $3\left(3.35 \mathrm{t} \mathrm{ha}^{-1}\right)$ and Env4 $\left(3.31 \mathrm{t} \mathrm{ha}^{-1}\right)$. However, it is noteworthy that the highest and the lowest values for SY were observed in the same location (Thessaloniki), with a very high difference $\left(3.38 \mathrm{tha}^{-1}\right)$ between years, indicating that this location is subjected to significant GEI.

The number of pods per plant (PP) ranged from 15.5 to 18.1 between genotypes and the number of seeds per plant (SP) from 48.8 to 57.6. Genotypes were not significantly different, with the exception of G4, which exhibited the lowest values, 14.4 and 43.6, for 
PP and SP, respectively. The two yield components (PP and SP) showed a very high correlation value (0.977) and a great similarity for their ranking among genotypes. This lack of genotypic differentiation for the yield components, combined with the relative low percentage of the total variation explained by the genotype for PP and SP, indicated that these characteristics were similar across the genotypes tested. Similar results were reported by other studies $[45,46]$. Regarding the environments, they also had the same ranking for PP and SP, whereas Env 3 and Env 4 did not differ and resulted in very close values.

The average thousand-seed weight of cultivars across environments was $484 \mathrm{~g}$. The highest thousand-seed weight was found at G2 (534 g), and the lowest was found at G5 $(371 \mathrm{~g})$. In the tested environments the highest $(585 \mathrm{~g})$ and lowest $(396 \mathrm{~g})$ mean thousandseed weights were recorded at Env6 and Env1, respectively. Thousand-seed weight was a characteristic that was affected by the environment and genotype equally. It is well known that TSW is highly heritable, as it is controlled by an additive gene action $[45,47]$, but the environmental conditions at the pod-filling period determine whether the expression of the genetic background will be at the higher level (optimal conditions) or at the lower level (drought) [10,48].

The time of flowering is a critical characteristic, as it contributes to drought tolerance, especially under Mediterranean conditions $[17,45]$, via the escape mechanism that concludes the grain-filling period before the terminal drought [49]. The time from sowing to flowering was in the range of 117-125 days among genotypes, with genotypes G1 and G6 being the earliest and G5 the latest. Genetic variation of these traits is essentially unknown for faba bean, especially in Mediterranean conditions [17]. However, in the present study genotypic effect for earliness was minimal, as the environment explained $>98 \%$ of the total variation. Significant differences were detected and completely differentiated the six environments. With the exception of Env1, where the short duration until flowering was due to the late sowing time caused by continuous heavy rainfall, in Env4 and Env6 (Larissa and Thessaloniki, respectively, in the second growing season) genotypes were boosted to reach the flowering period earlier by 23 and 24 days, respectively, compared to Env3 and Env5 (Larissa and Thessaloniki, respectively, in the first growing season). This could be attributed to higher temperatures that prevailed during the vegetative period in the second growing season $\left(9.11^{\circ} \mathrm{C}\right.$ vs $9.55^{\circ} \mathrm{C}$ and $8.78^{\circ} \mathrm{C}$ vs $9.23^{\circ} \mathrm{C}$ for the first and second growing season in Larissa and Thessaloniki, respectively). This is consistent with the findings of other studies [50,51].

Plant height was another trait that showed significant variation in the different environments, as it was affected by the environment (93\%) and ranged from 69.4 up to $129.6 \mathrm{~cm}$ across environments and genotypes. This range was in agreement with the desirable range for faba bean plants $(70-140 \mathrm{~cm})$, because within this plant height range they can efficiently suppress weeds and are tolerant/resistant to lodging [46]. Similar to other studies [37,45,52], the strongest positive correlation was found between plant height and biomass, followed by earliness and seed yield, and thus plant height could be used as an indirect selection criterion for biomass yield.

\subsection{Water Use Efficiency}

Water deficit is considered a major constraint to faba bean growth and production. Yield-sensitive phenological stages of faba bean crop to drought stress are flowering and pod development, with yield losses up to $50 \%$ during early pod-setting. These stages coincide with the spring and early summer months under semi-arid Mediterranean conditions where high temperatures, particularly when combined with drought, lead to flower abortion, a lower number of pods, and reduce seed yield [17,53-55]. Water use efficiency is a measure of the amount of biomass produced per unit of water used by a plant and has been proposed in plant breeding to identify genotypes that have high assimilation rates under temperature and water deficit stress [56]. In our study, genotypes differed for $W_{U E}$ and WUE $E_{S Y}$. Genotypes G4 and G3, which were the two high yielders for biomass yield, showed the highest values for $\mathrm{WUE}_{\mathrm{BY}}$, whereas genotypes $\mathrm{G} 6$ and $\mathrm{G1}$, which ranked 
in the top for $W U E_{S Y}$, were also the highest yielding genotypes for seed yield $[54,57,58]$. In particular, both genotypes flower earlier and produce high seed yield under low rainfall environments, as they can set pods and seeds early in the season $[17,59,60]$. WUE between environments ranged from $2.09 \mathrm{~kg} \mathrm{ha}^{1} \mathrm{~m}^{-3}$ (Env1) up to $4.95 \mathrm{~kg} \mathrm{ha}^{1} \mathrm{~m}^{-3}$ (Env4) for biomass yield and from $0.37 \mathrm{~kg} \mathrm{ha}^{1} \mathrm{~m}^{-3}$ (Env5) up to $1.43 \mathrm{~kg} \mathrm{ha}^{1} \mathrm{~m}^{-3}$ (Env6) for seed yield, which are similar to the values that were reported in other studies for dry matter production $3 \mathrm{~kg} \mathrm{ha}^{1} \mathrm{~m}^{-3}$ and for seed yield $1.3 \mathrm{~kg} \mathrm{ha}^{1} \mathrm{~m}^{-3}$ [57,61]. In addition, the more productive environments Env4, Env6, and Env3 for biomass yield and Env6 for seed yield demonstrated higher WUE values.

\subsection{GxE Plot Analysis}

The general ANOVA showed that the effect of genotype $(G)$, environment $(E)$, and genotype by environment interaction (GEI) were highly significant in most characteristics, indicating that the genotypes showed significantly different performance and also different ranking in the environments that were tested. As a consequence, different winning genotypes for each environment were detected, indicating the presence of crossover-type GEI [62]. The presence of crossover GEI could be attributed to the differences among the genotypes and the environments that were characterized by differences in weather conditions, soil types, and rainfall distribution. However, the environment was the main source of variability $(>80 \%)$ between genotypes for biomass and seed yield. A similar response was found in other multi-environmental trials with faba bean, where the environment had the highest contribution to the total variation, followed by GEI $[23,25]$.

The genotype G4 can be defined as well adapted for biomass yield, as it performed consistently and produced higher than the mean yield of all the genotypes under the environments tested. On the other hand, genotype G6 was the most productive and stable for seed production. Genotype G3 performed with high stability and production capacity for both biomass and seed yield and could be characterized as a widely adapted genotype under typical Mediterranean environments, whereas G5 was the most unstable and least productive genotype for both traits. The stable and productive genotypes can be suggested as potential sources of stability alleles and can be utilized in breeding programs [63]. In particular, genotype G3 combines high biomass and seed yield with an indeterminate growth habit, a medium maturity period, and high values of WUE, which makes it suitable for the prevailing climate change and weather variability.

\section{Conclusions}

In the present study, we observed large variations in biomass, seed yield, and yield components in the six environments used. Most traits were mainly affected by the environment, and only the thousand-seed weight was equally affected by the genotype. Nevertheless, it was possible to identify high-yielding and stable faba bean genotypes for biomass, seed yield, or both traits by conducting multi-environmental trials that respond better under Mediterranean conditions.

Author Contributions: Conceptualization, P.P. (Panayiota Papastylianou), D.N.V., and C.D.; methodology, P.P. (Panayiota Papastylianou), D.N.V., and C.D.; validation, E.T. (Evangelia Tigka); formal analysis, E.T. (Evangelia Tigka), I.M., A.K. (Angeliki Kousta), and P.P. (Paschalis Papakaloudis); investigation, E.T. (Evangelia Tigka), A.K. (Angeliki Kousta), A.K. (Anastasia Kargiotidou), P.P. (Paschalis Papakaloudis), E.P., A.K. (Avraam Koskosidis), C.P., P.P. (Paschalis Papakaloudis), M.K., and S.K.; writing—original draft preparation, E.T. (Evangelia Tigka), A.K. (Anastasia Kargiotidou), I.M., A.K. (Angeliki Kousta), P.P. (Paschalis Papakaloudis), E.T. (Eleni Tani), and E.M.A.; writing-review and editing, P.P. (Panayiota Papastylianou), D.N.V., and C.D.; visualization, P.P. (Panayiota Papastylianou) and I.M.; supervision, P.P. (Panayiota Papastylianou); project administration, E.M.A. and E.T. (Eleni Tani). All authors have read and agreed to the published version of the manuscript.

Funding: This research was co-financed by the European Regional Development Fund of the European Union and Greek national funds through the Operational Program Competitiveness, En- 
trepreneurship and Innovation, under the call RESEARCH-CREATE-INNOVATE (project code: T1EDK-04448).

Institutional Review Board Statement: Not applicable.

Informed Consent Statement: Not applicable.

Data Availability Statement: The data presented in this study are available on request from the corresponding author. The data are not publicly available due to privacy restrictions.

Conflicts of Interest: The authors declare no conflict of interest.

\section{References}

1. Afzal, M.; Shabbir, G.; Ilyas, M.; Jan, S.S.A.; Jan, S.A. Impact of climate change on crop adaptation: Current challenges and future perspectives. Pure Appl. Biol. 2018, 7, 965-972. [CrossRef]

2. Kole, C.; Muthamilarasan, M.; Henry, R.; Edwards, D.; Sharma, R.; Abberton, M.; Batley, J.; Bentley, A.; Blakeney, M.; Bryant, J.; et al. Application of genomics-assisted breeding for generation of climate resilient crops: Progress and prospects. Front. Plant Sci. 2015, 6, 563. [CrossRef] [PubMed]

3. Lammerts van Bueren, E.T.; Struik, P.C.; van Eekeren, N.; Nuijten, E. Towards resilience through systems-based plant breeding. $A$ review. Agron. Sustain. Dev. 2018, 38, 42. [CrossRef]

4. Duc, G.; Agrama, H.; Bao, S.; Berger, J.; Bourion, V.; de Ron, A.M.; Gowda, C.L.L.; Mikic, A.; Millot, D.; Singh, K.B.; et al. Breeding Annual Grain Legumes for Sustainable Agriculture: New Methods to Approach Complex Traits and Target New Cultivar Ideotypes. Crit. Rev. Plant Sci. 2015, 34, 381-411. [CrossRef]

5. Cernay, C.; Ben-Ari, T.; Pelzer, E.; Meynard, J.-M.; Makowski, D. Estimating variability in grain legume yields across Europe and the Americas. Sci. Rep. 2015, 5, 1-11. [CrossRef] [PubMed]

6. Watson, C.A.; Reckling, M.; Preissel, S.; Bachinger, J.; Bergkvist, G.; Kuhlman, T.; Lindström, K.; Nemecek, T.; Topp, C.F.; Vanhatalo, A.; et al. Grain Legume Production and Use in European Agricultural Systems. Adv. Agron. 2017, 144, $235-303$.

7. Bahl, P.N. Climate Change and Pulses: Approaches to Combat Its Impact. Agric. Res. 2015, 4, 103-108. [CrossRef]

8. Zohary, D.; Hopf, M. Domestication of Plants in the Old World, 3rd ed.; Oxford University Press: Oxford, UK, $2000 ;$ p. 316.

9. Crépon, K.; Marget, P.; Peyronnet, C.; Carrouée, B.; Arese, P.; Duc, G. Nutritional value of faba bean (Vicia faba L.) seeds for feed and food. Field Crops Res. 2010, 115, 329-339.

10. Duc, G.; Aleksić, J.M.; Marget, P.; Mikić, A.; Paull, J.; Redden, R.J.; Sass, O.; Stoddard, F.L.; Vandenberg, A.; Vishnyakova, M.; et al. Faba Bean. In Grain Legumes; de Ron, A.M., Ed.; Springer: New York, NY, USA, 2015; pp. 141-178.

11. Köpke, U.; Nemecek, T. Ecological services of faba bean. Field Crops Res. 2010, 115, 217-233. [CrossRef]

12. Suso, M.J.; del Río, R. A crop-Pollinator inter-play approach to assessing seed production patterns in faba bean under two pollination environments. Euphytica 2015, 201, 231-251. [CrossRef]

13. Zong, X.; Yang, T.; Liu, R. Faba Bean (Vicia Faba L.) Breeding. In Advances in Plant Breeding Strategies: Legumes; Al-Khayri, J.M., Jain, S.M., Johnson, D.J., Eds.; Springer: Cham, Switzerland, 2019; pp. 245-286.

14. Food and Agriculture Organization of the United Nations. FAOSTAT. Available online: www.fao.org/faostat/en/\#data/QC (accessed on 14 December 2020).

15. Sillero, J.C.; Villegas-Fernández, A.M.; Thomas, J.; Rojas-Molina, M.M.; Emeran, A.A.; Fernández-Aparicio, M.; Rubiales, D. Faba bean breeding for disease resistance. Field Crops Res. 2010, 115, 297-307. [CrossRef]

16. Link, W.; Balko, C.; Stoddard, F.L. Winter hardiness in faba bean: Physiology and breeding. Field Crops Res. 2010, 115, 287-296. [CrossRef]

17. Khan, H.R.; Paull, J.G.; Siddique, K.H.M.; Stoddard, F.L. Faba bean breeding for drought-affected environments: A physiological and agronomic perspective. Field Crops Res. 2010, 115, 279-286. [CrossRef]

18. Jensen, E.S.; Peoples, M.B.; Hauggaard-Nielsen, H. Faba bean in cropping systems. Field Crops Res. 2010, 115, 203-216. [CrossRef]

19. Pérez-de-Luque, A.; Eizenberg, H.; Grenz, J.H.; Sillero, J.C.; Ávila, C.; Sauerborn, J.; Rubiales, D. Broomrape management in faba bean. Field Crops Res. 2010, 115, 319-328. [CrossRef]

20. Stoddard, F.L.; Nicholas, A.G.; Rubiales, D.; Thomas, J.; Villegas-Fernández, A.M. Integrated pest management in faba bean. Field Crops Res. 2010, 115, 308-318. [CrossRef]

21. Singh, A.K.; Bharati, R.C.; Manibhushan, N.C.; Pedpati, A. An assessment of faba bean (Vicia faba L.) current status and future prospect. Afr. J. Agric. Res. 2013, 8, 6634-6641.

22. Maalouf, F.; Hu, J.; O'Sullivan, D.M.; Zong, X.; Hamwieh, A.; Kumar, S.; Baum, M. Breeding and genomics status in faba bean (Vicia faba). Plant Breed. 2019, 138, 465-473. [CrossRef]

23. Temesgen, T.; Keneni, G.; Sefera, T.; Jarso, M. Yield stability and relationships among stability parameters in faba bean (Vicia faba L.) genotypes. Crop J. 2015, 3, 258-268. [CrossRef]

24. Sharifi, P.; Aminpanah, H.; Erfani, R.; Mohaddesi, A.; Abbasian, A. Evaluation of genotype x environment interaction in rice based on AMMI model in Iran. Rice Sci. 2017, 24, 173-180. [CrossRef]

25. Gurmu, F.; Lire, E.; Asfaw, A.; Alemayehu, F.; Rezene, Y.; Ambachew, D. GGE-biplot analysis of grain yield of faba bean genotypes in southern Ethiopia. Electron. J. Plant Breed. 2012, 3, 898-907. 
26. Meier, U. Growth Stages of Mono- and Dicotyledonous Plants. BBCH Monograph, 2nd ed.; Blackwell Science: Berlin, Germany, 2001; p. 158.

27. Steel, R.G.D.; Torrie, J.H.; Dickey, D. Principles and Procedures of Statistics: A Biometrical Approach, 3rd ed.; McGraw Hill: New York, NY, USA, 1980; p. 672.

28. Yan, W. GGEbiplot-A Windows application for graphical analysis of multi-environment trial data and other types of two-way data. Agron. J. 2001, 93, 1111-1118. [CrossRef]

29. Yan, W. Singular-value partitioning in biplot analysis of multi-environment trial data. Agron. J. 2002, 94, 990-996. [CrossRef]

30. Payne, R.W. GenStat. Wiley Interdiscip. Rev. Comput. Stat. 2009, 1, 255-258. [CrossRef]

31. Mwiinga, B.; Sibiya, J.; Kondwakwenda, A.; Musvosvi, C.; Chigeza, G. Genotype x environment interaction analysis of soybean (Glycine max (L.) Merrill) grain yield across production environments in Southern Africa. Field Crop. Res. 2020, $256,107922$.

32. Flores, F.; Nadal, S.; Solis, I.; Winkler, J.; Sass, O.; Stoddard, F.L.; Link, W.; Raffiot, B.; Muel, F.; Rubiales, D.; et al. Faba bean adaptation to autumn sowing under European climates. Agron. Sustain. Dev. 2012, 32, 727-734. [CrossRef]

33. Reckling, M.; Döring, T.F.; Bergkvist, G.; Chemielewski, F.-M.; Stoddard, F.L.; Watson, C.A.; Sedding, S.; Bachinger, J. Grain legume yield instability has increased over 60 years in long-term experiments as measured by a scale-adjusted coefficient of variation. Asp. Appl. Biol. 2018, 138, 15-20.

34. Stoddard, F.L.; Balko, C.; Erskine, W.; Khan, H.R.; Link, W.; Sarker, A. Screening techniques and sources of resistance to abiotic stresses in cool-season food legumes. Euphytica 2006, 147, 167-186. [CrossRef]

35. Boote, K.J.; Mínguez, M.I.; Sau, F. Adapting the CROPGR legume model to simulate growth of faba bean. Agron. J. 2002, 94, 743-756. [CrossRef]

36. Lake, L.; Godoy-Kutchartt, D.E.; Calderini, D.F.; Verrell, A.; Sadras, V.O. Yield determination and the critical period of faba bean (Vicia faba L.). Field Crop. Res. 2019, 241, 107575. [CrossRef]

37. Link, W.; Abdelmula, A.A.; von Kittlitz, E.; Bruns, S.; Riemer, H.; Stelling, D. Genotypic variation for drought tolerance in Vicia faba. Plant Breed. 1999, 118, 477-483. [CrossRef]

38. Kazai, P.; Noulas, C.; Khah, E.; Vlachostergios, D. Yield and seed quality parameters of common bean cultivars grown under water and heat stress field conditions. AIMS Agric. Food 2019, 4, 285-302. [CrossRef]

39. Skovbjerg, C.K.; Knudsen, J.N.; Füchtbauer, W.; Stougaard, J.; Stoddard, F.L.; Janss, L.; Andersen, S.U. Evaluation of yield, yield stability and yield-protein relationship in 17 commercial faba bean cultivars. Legume Sci. 2020, 2, 1-11. [CrossRef]

40. Karimizadeh, R.; Mohammadi, M.; Sabaghni, N.; Mahmoodi, A.A.; Roustami, B.; Seyyedi, F.; Akbari, F. GGE biplot analysis of yield stability in multi-environment trials of lentil genotypes under rainfed conditions. Not. Sci. Biol. 2013, 5, 256-262. [CrossRef]

41. Galanopoulou, K.; Lithourgidis, A.S.; Dordas, C.A. Intercropping of faba bean with barley at various spatial arrangements affects dry matter and N yield, nitrogen nutrition index, and interspecific competition. Not. Bot. Horti Agrobot. Cluj-Napoca 2019, 47, 1116-1127.

42. Etemadi, F.; Hashemi, M.; Zandvakili, O.; Mangan, F.X. Phenology, yield and growth pattern of faba bean varieties. Int. J. Plant Prod. 2018, 12, 243-250. [CrossRef]

43. Di Paolo, E.; Garofalo, P.; Rinaldi, M. Irrigation and nitrogen fertilization treatments on productive and qualitative traits of broad bean (Vicia faba var. minor L.) in a Mediterranean environment. Legume Res. 2015, 38, 209-218.

44. Youseif, S.H.; El-Megeed, F.H.A.; Saleh, S.A. Improvement of faba bean yield using Rhizobium/Agrobacterium inoculant in low-fertility sandy soil. Agronomy 2017, 7, 2. [CrossRef]

45. Bodner, G.; Kronberga, A.; Lepse, L.; Olle, M.; Vågen, I.M.; Rabante, L.; Fernández, J.A.; Ntatsi, G.; Balliu, A.; Rewald, B. Trait identification of faba bean ideotypes for Northern European environments. Eur. J. Agron. 2018, 96, 1-12. [CrossRef]

46. Olle, M.; Williams, I.H.; Rosa, E. Selecting appropriate faba bean var. minor varieties for production under Northern European environmental conditions. Acta Agric. Scand. B Soil Plant Sci. 2019, 69, 432-438.

47. Toker, C. Estimates of broad-sense heritability for seed yield and yield criteria in faba bean (Vicia faba L.). Hereditas 2004, 140, 222-225. [CrossRef]

48. Alan, O.; Geren, H. Evaluation of heritability and correlation for seed yield and yield components in faba bean (Vicia faba L.). J. Agron. 2007, 6, 484-487.

49. Duc, G.; Link, W.; Marget, P.; Redden, R.J.; Stoddard, F.L.; Torres, A.M.; Cubero, J.I. Genetic Adjustment to Changing Climates: Faba Bean. In Crop Adaptation to Climate Change; Yadav, S.S., Redden, R.J., Hatfield, J.L., Lotze-Campen, H., Hall, A.E., Eds.; Wiley: Oxford, UK, 2011; pp. 269-286.

50. Patrick, J.W.; Stoddard, F.L. Physiology of flowering and grain filling in faba bean. Field Crops Res. 2010, 115, 234-242. [CrossRef]

51. Catt, S.C.; Paull, J.G. Effects of ambient temperature and photoperiod on flowering time in Faba bean (Vicia faba L.). Crop Pasture Sci. 2017, 68, 893-901. [CrossRef]

52. Ulukan, H.; Guler, M.; Keskin, S. A path coefficient analysis some yield and yield components in faba bean (Vicia faba L.) genotypes. Pak. J. Biol. Sci. 2003, 6, 1951-1955. [CrossRef]

53. Mwanamwenge, J.; Loss, S.P.; Siddique, K.H.M.; Cocks, P.S. Effect of water stress during floral initiation, flowering and podding on the growth and yield of faba bean (Vicia faba L.). Eur. J. Agron. 1999, 11, 1-11. [CrossRef]

54. Alghamdi, S.S.; Al-Shameri, A.M.; Migdadi, H.M.; Ammar, M.H.; El-Harty, E.H.; Khan, M.A.; Farooq, M. Physiological and molecular characterization of faba bean (Vicia faba L.) genotypes for adaptation to drought stress. J. Agron. Crop Sci. 2015, 201, 401-409. 
55. Muktadir, M.A.; Adhikari, K.N.; Merchant, A.; Belachew, K.Y.; Vandenberg, A.; Stoddard, F.L.; Khazaei, H. Physiological and Biochemical Basis of faba Bean Breeding for Drought Adaptation-A Review. Agronomy 2020, 10, 1345. [CrossRef]

56. Hatfield, J.L.; Dold, C. Water-use efficiency: Advances and challenges in a changing climate. Front. Plant Sci. 2019, 10, 103. [CrossRef] [PubMed]

57. Siddique, K.H.M.; Regan, K.L.; Tennant, D.; Thomson, B.D. Water use and water use efficiency of cool season grain legumes in low rainfall Mediterranean-type environments. Eur. J. Agron. 2001, 15, 267-280. [CrossRef]

58. Desoky, E.M.; Mansour, E.; Yasin, M.A.T.; El-Sobky, E.E.A.; Rady, M.M. Improvement of drought tolerance in five different cultivars of Vicia faba with foliar application of ascorbic acid or silicon. Span. J. Agric. Res. 2020, 18, e0802. [CrossRef]

59. Mwanamwenge, J.; Loss, S.P.; Siddique, K.H.M.; Cocks, P.S. Growth, seed yield and water use of faba bean (Vicia faba L.) in a short-season Mediterranean-type environment. Aust. J. Exp. Agric. 1998, 38, 171-180.

60. Zeleke, K.; Nendel, C. Growth and yield response of faba bean to soil moisture regimes and sowing dates: Field experiment and modelling study. Agric. Water Manag. 2019, 213, 1063-1077. [CrossRef]

61. Zabawi, A.G.M.; Dennet, M.D.D. Responses of faba bean (Vicia faba L. cv. Maris Bead) to different levels of plant available water. II. Yield, water use and water use efficiency. J. Trop. Agric. Food Sci. 2010, 38, 145-152.

62. Tukamuhabwa, P.; Asiimwe, M.; Nabasirye, M.; Kabayi, P.; Maphosa, M. Genotype by environment interaction of advanced generation soybean lines for grain yield in Uganda. Afr. Crop Sci. J. 2012, 20, 107-115.

63. Annicchiarico, P. Genotype $\times$ Environment Interactions: Challenges and Opportunities for Plant Breeding and Cultivar Recommendations; Food and Agriculture Organization: Rome, Italy, 2002; pp. 5-12. 